\section{A IIS natatent}

Journal of

Islamic Studies
Institut Agama Islam Negeri (IAIN) Curup, Indonesia

ISSN 2580-3174, (p); 2580-3190 (e)

volume 6, number 1, 2021 | page: 135-146

DOI: http://doi.org/10.29240/ajis.v6i1.2751

\title{
Early Marriage in Medical View and Maqashid Sharia
}

\author{
Rifanto bin Ridwan' ${ }^{1}$, Ifnaldi ${ }^{2}$, Jahidin ${ }^{3}$ \\ Institut Agama Islam Negeri (AIN) Curup, Indoneisa \\ gubug64@gmail.com,ifnaldi@iaincurup.ac.id,mjahidin817@gmail.com
}

\begin{abstract}
This article aims to find out how the medical and legal views of Islam (Maqashid Sharia) on marriages are carried out by minors. Through library research methods, this study found; 1) from a medical point of view, early marriage is not recommended. Because it can harm the reproductive health of women who are still in their infancy. Mentally, the perpetrators will feel inferior and less able to control their emotions due to emotional unpreparedness, 2) in terms of Maqashid Sharia, early marriage should be avoided. Because, although the goal of Sharia, namely maintaining offspring, is fulfilled, in practice it often causes problems, so that the purpose of marriage, which is getting sakinah mawaddah wa rahmah, is not achieved..
\end{abstract}

Keywords: Early marriage, Health, Maqashid Syariah

\section{Introduction}

Early marriage is never boring to discuss, every time discussing early marriage there are always new problems that must be resolved. At first, it was not a problem, and even tended to be entrenched, but along with the times and changing perspectives, early marriage became something that should be avoided.

Women are the most disadvantaged parties in early marriage, almost all the negative impacts due to early marriage return to women. That is because of the natural nature of a woman who will carry out the natural process as a logical consequence of marriage, marrying, channeling biological needs, conceiving, and giving birth.

In 2013 the world was shocked by the news of the death of Nayla Maknun (not her real name) from Hardh - Southwest Yemen, NM who was only 8 years old after experiencing heavy bleeding. Tragically, this incident occurred on the first night of her marriage to a man who was five times her age. NM suffered heavy bleeding and internal injuries as a result of his physical and mental unpreparedness for his first night. 
The results of other studies show that early marriage couples experience miscarriages caused by the mother's uterus not being strong enough. In addition, almost $50 \%$ of early married couples end in divorce.

The Indonesian government is trying its best to prevent early marriage, by enacting laws that limit the age at which marriage is allowed, such as Law no. 1 of 1974 concerning marriage which limits the minimum age for marriage at the age of 16 for women and 19 years for men. This law was revised with Law N0. 16 of 2019 which limits the age allowed to marry at the age of 19 , both for women and men.

While in Islam there is no minimum age limit for marriage. The Qur'an hints at the permissibility of getting married at a young age. History also tells that many friends got married at a very young age. Siti Aisyah is reported to have married at the age of 6 , in another narration she married at the age of 8 and some even report that she married at an adult age. Amr ibn al-'Ash and his son Abdullah ibn Amr ibn al-'Ash were only 11 years apart.

The majority believe that marriage must be done after the bride and groom enter adulthood. Mature in the sense that the prospective bride and groom have understood and understood the meaning of marriage and the consequences that will be faced after the marriage contract takes place. But unfortunately, there is no standard age limit that can be relied on in determining a person's maturity.

Indonesian Law Number 1 of 1974 concerning Marriage does not stipulate the age limit for a person's maturity. The law only regulates parental permission for people who will marry if they have not reached the age of 21 years $^{1}$. The law also stipulates the lowest age limit for a person to obtain a marriage license when it is 19 years old for men and 16 years old ${ }^{2}$. This means that for someone who wants to get married while they are not yet 21 years old, that person must get permission from their parents, and the minimum limit for someone to get permission from both parents is 19 for men and 16 for women. The law also clarifies that a child who has not reached the age of 18 years or has never been married,

\footnotetext{
1 Republic of Indonesia Law No. 1 of 1974, Article 6 paragraph 2

2 Republic of Indonesia Law No. 1 of 1974, Article 7 paragraph 2
} 
is under the control of his parents ${ }^{3}$, or is under the authority of his guardian ${ }^{4}$.

The marriage law above shows that the legal age for marriage for men is at least 19 years and for women, it cannot be less than 16 years, subject to the approval of both parents. So someone who is married under 19 years for men and 16 for women can be categorized as early marriage.

Every rule always has exceptions, usually, exceptions are given when the situation is urgent. Likewise, the condition of the Marriage Law still provides space for prospective brides who are still under the specified age to carry out marriages on the condition that they seek permission from the Religious Courts to justify them carrying out the marriage. For the bride and groom who are not old enough and want to get permission from the court, even if they can carry out the marriage, they cannot get out of the early marriage. This means that their marriage is called an early marriage, even though they get permission from the government, which is because their age is still below the standard set by law.

According to Law Number 23 of 2002 concerning Child Protection: children are those under the age of 18 years, including fetuses that are still in the womb ${ }^{5}$. Then in another article, it is also emphasized that the family and parents are obliged to prevent marriage at an early age ${ }^{6}$.

This law limits the age of marriage for a child to 18 years old regardless of gender. So anyone who gets married under that age can be categorized as early marriage. This Act strictly prohibits the marriage of children under the age of 18 years, urges parents and close families of children not to allow the marriage of children who have not yet reached the age of 18 .

The description above raises the question, what is the impact of early marriage on the perpetrators? Medically, early marriage is justified,

\footnotetext{
${ }^{3}$ Republic of Indonesia Law No. 1 of 1974, Article 47 paragraph 2

${ }^{4}$ Republic of Indonesia Law No. 1 of 1974, Article 50 paragraph 2

${ }^{5}$ Law Number 23 of 2003 concerning Child Protection, Article 1

${ }^{6}$ Law Number 23 of 2003 concerning Child Protection, Article 26 paragraph 1
} point c 
and according to Islamic law, can it fulfill the purpose of marriage? This is what the author tries to discuss in this article, which is to reveal the medical and maqashid views of Sharia on early marriage. This issue is discussed by exploring the literature, reviewing various opinions about it, and analyzing it from the medical and Islamic legal perspectives.

Several studies on early marriage have been widely discussed, such as those conveyed by Achrory and Siska Iriani ${ }^{7}$, Kamarusdiana and Ita Sofia ${ }^{8}$, Dwi Rifiani ${ }^{9}$, and Habibah Nurul Umah ${ }^{10}$. These studies focus on discussing the views of Islamic law on early marriage. This research has novelty from another point of view, namely the medical side.

\section{Early Marriage in Medical View}

One of the purposes of marriage is to produce offspring, of course, in a good and right way from the side of health and religious norms. The government sets the minimum age for marriage as a form of government concern for the safety of its citizens who want to get married. Suryono firmly stated that limiting the age of marriage is purely for the sake of health, especially for women who will have a direct impact on the event of marriage ${ }^{11}$.

Law No. 1 of 1974 in article 7 paragraph 2 limits marriage at the age of 19 for men and 16 years for women ${ }^{12}$. This restriction aims to

\footnotetext{
${ }^{7}$ Achrory dan Siska Iriani, "Fenomena Pernikahan Dini Dalam Perspektif Islam $153-161$

(Studi Kasus Di Desa Kalikuning)”, Jurnal Penelitian Keislaman, 14(2), 2018,

${ }^{8}$ Kamarusdiana dan Ita Sofia, "Dispensasi Nikah Dalam Perspektif Hukum Islam, Undang-Undang Nomor 1 Tahun 1974 dan Kompilasi Hukum Islam", SALAM; Jurnal Sosial \& Budaya Syar-i, 7(1), 2020, pp.49-64, DOI: 1 10.15408/sjsbs.v7i1.14534

${ }^{9}$ Dwi Rifiani, "Pernikahan Dini Dalam Perspektif Hukum Islam", de Jure, Jurnal Syariah dan Hukum, 3(2), 2011, 125-134

${ }_{10}$ Habibah Nurul Umah, "Fenomena Pernikahan Dini di Indonesia Perspektif Hukum-Keluarga-Islam”, Jurnal Al Wasith: Jurnal Studi Hukum Islam, 5(2), 2020, 107 125

11 Marieyam, "Pelaksanaan Perkawinan Usia Dini Setelah Berlakunya UU RI Nomor 1 Tahun 1974 " Tesis. ( Semarang: Perpustakaan Universitas Diponegoro Semarang 2017).

${ }^{12}$ Law no. 16 of 2019 which has been revised the minimum age for marriage is 19 , both male and female.
} 
protect the bride and groom from all sides of their lives, both spiritually and psychologically. The following points strengthen this opinion:

a. In marriage, the woman is most affected by the consequences of this event, because her nature as a woman will be pregnant. In the process of conceiving, both physical and psychological strength are required simultaneously. Even according to the National Family Planning Coordinating Board (BKKBN) a woman's readiness to conceive and give birth or have children is determined by readiness in three ways, namely physical readiness, mental (emotional/psychological) readiness, and social/economic readiness. ${ }^{13}$

b. Physically a woman will experience rapid physical development at puberty, then this development will end at the age of 19-20 years, at this age a woman may be said to have matured physically. Women who marry before the age of 16 are essentially still in a transition period, all of their physical anatomies are in the process of reaching maturity. According to BKKBN In general, a woman is said to be physically ready if she has completed her body growth (when her body stops growing), which is around the age of 20 years. So that the age of 20 years can be used as a guide for physical readiness

c. Psychologically, women who marry at the age of under 16 years do not have emotional/mental readiness which will have an impact on disharmony with their partners.

d. One of the factors of physical unpreparedness is that the reproductive organs are still not strong enough, so it is not uncommon for couples at an early age to miscarry, or give birth to an unhealthy child so that they eventually die in infancy ${ }^{14}$.

e. Mental unpreparedness can also be seen in couples at an early age after giving birth, often panicking when caring for their children, especially when the child is sick so that they are more comfortable leaving their child to their grandmother. It's not the busyness factor so they have to

${ }^{13}$ Suryono, Pernikahan Dini Pada Masyarakat Lebong Utara : Tinjauan Sosiologis dan Normatif, Tesis, (Curup-IAIN Curup), 92

${ }^{14}$ Ibid. 
leave the child, but rather the mental unpreparedness in taking care of the child.

f. Socio-economic is the position or position of a person in a community group which is determined by the type of economic activity, education, and income. Since the colonial era, education is considered an important factor to improve the welfare of the nation. The connection with early childhood partners is that they are still in the childhood age that is required to study. Refers to the government's program regarding 12-year compulsory education following government recommendations ${ }^{15}$. Where ages 7-19 are required to attend education, children at that age are allowed to study with both the central and regional governments who are responsible for the implementation of the program. At this age, the child's ability to carry out economic activities is certainly not maximized or even minimal. So it is natural that children aged 16 years and under are still very difficult to realize an affluent economic condition.

\section{Early Marriage in Maqashid Analysis}

Maqashid al-Syariah or the purpose of Islamic law is to ensure that all matters ordered and prohibited by Islam are beneficial ${ }^{16}$. All these cases must be based on the principles of Jalbul Mashalih and Daf'ul Mafasid (taking and rejecting the bad) ${ }^{17}$. As Allah says in Surah al-Hashr, 59:7:

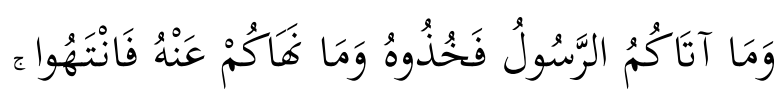

"What the Messenger gave you, take it. Leave what he forbids".

15 Indonesia Law No. 20 of 2003 concerning the National Education system and Government Regulation of the Republic of Indonesia No. 47 of 2008 concerning Compulsory Education. It is stated that the government's obligation to carry out compulsory education at the elementary and junior high school levels or the equivalent, while the 9-year compulsory education program for ages 7-19 years, the government is still working on its implementation, one of the goals of which is to reduce the occurrence of early marriage. 1999), 396

${ }^{16}$ Ibrahim Mustafa, al-Mu'jam al-Wasith, (Istanbul : al-Maktabah al-Islamiyyah,

${ }^{17}$ Asafri Jaya Bakri, Konsep Maqashid al_syari'ah menurut al-syatibi, (Jakarta: PT Raja Grafindo, 1996), 61 
The verse above explains that if the Messenger of Allah ordered something, it must be carried out, as, for something that is prohibited, it must be abandoned ${ }^{18}$. Commands and prohibitions that are sourced from the Prophet Muhammad certainly contain goodness and wisdom that are the basis of Islamic law ${ }^{19}$.

So events and cases that are directly or indirectly related to early marriage that contains benefits can be done, while those that invite harm must be avoided. If an event that contains benefits and harm is collected simultaneously, then the first thing that needs to be done is to eliminate the harm first ${ }^{20}$. As outlined in the rules of fiqhiyyah:

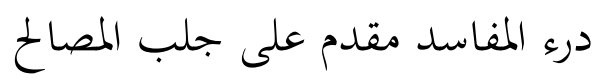

Refusing mafsadah (damage) takes precedence over taking benefit.

Here are some views of maqashid in early marriage:

a. In Islam, marriage is worship as a means to get closer to Allah ${ }^{21}$. He is half of the religion, a person's religion is not perfect if he is not married. Therefore, marriage is a sacred moment for each individual and must be prepared well. In addition, marriage is a basic right for every individual in continuing his life journey, every individual may marry anytime and anywhere. There is no limit on certain individuals to get married. But lately, some parties want to arrange marriage by limiting the age of the bride and groom who want to get married. Not only in Indonesia but several countries in the world are also doing the same thing.

b. Limiting the age of marriage, of course, has gone through a long thought process and experience, the birth of Law no. 1 of 1974 which later appeared its revision through Law no. 16 of 2019 which

18 Andopa, A., Hardivizon, H., \& Yunita, N. (2018). The Meaning of Nafs in the Qur'an Based on Quraish Shihab's Interpretation. AJIS: Academic Journal of Islamic Studies, 3(2), 139-162. doi:http://dx.doi.org/10.29240/ajis.v3i2.578

19 Yusuf Qaradhawi, Membumikan Syari'at Islam, Keluwesan aturan Illahi untuk Manusai, (Bandung: Pustaka Mizan, 2003), Cet.ke I, Hal 13

${ }^{20}$ Amir Syarifudin, Garis-Garis Besar Fiqh, (Jakarta: Kencana, 2003), 2-3

${ }^{21}$ Muhammad Said Ramadhan al-Buthy, Dawabit al-maslahah fi al-syariah alIslamiyyah, (Beirut:Dar al-Muttahidah, 1992), 108 
stipulates the minimum age limit for marriage is 19 years for both men and women. But again, even though there is an age restriction, there is still a way for people who are not old enough, but there is a strong desire to get married or are forced to marry ${ }^{22}$. For those who are not old enough and want to get married, they can request an exception from the local Religious Court, if the reasons put forward are reasonable and acceptable, the Religious Court will issue a recommendation letter for the person concerned to be allowed to marry. In essence, restrictions do not mean a barrier but as a form of prevention for the bride and groom to be better prepared to face the weight of a household journey that is full of challenges. Looking at the habit that humans at a young age are not physically and mentally mature, it is estimated that early marriage couples will find these problems, even the worst consequences will also apply to them. The BKKBN explains that many early marriages end in divorce, according to National data that $50 \%$ of their marriages end in divorce. What a fantastic percentage ratio ${ }^{23}$.

c. Age does not necessarily guarantee that marriage will last forever until death, all hope that their marriage lasts a lifetime. Not a few married couples of adult age make talaq as the final path of their household and there are also early age couples who have succeeded in building a household and lasting until old age. Marriage requires maturity in attitude and maturity in action. It is not uncommon for people of mature age to be less mature in responding to the prevailing events so that their actions are like children, but although, rarely, there are also people who are young in terms of age, their attitudes and actions exceed their age. But in general, young age is synonymous with immaturity both physically and mentally.

d. The purpose of marriage is to maintain human survival, by marrying someone will have offspring. With offspring, human life will be

22 Jaih Mubarak, Metodologi Ijtihad Hukum Islam, (Jogjakarta: UII Press, 2002),

${ }^{23}$ Ahmad Raysuni dan Muhammad Jamal Barut, Ijtihad anatara teks, realitas dan kemaslahatan sosial (Jakarta:Erlangga, 2002), 15 
longer ${ }^{24}$. Protecting and nurturing offspring is one of the goals of Islam. Imam Syatibi when discussing Maqashid al-Syariah made Hifz al-Nasl the fourth goal. To maintain this lineage, Islam stipulates marriage, making it half of the religious teachings ${ }^{25}$. In Islam, people who do not want to get married are considered as people who are less than perfect in their religion, even the Prophet SAW characterizes people who do not want to marry while they are capable of being not part of his community. The Messenger of Allah said in a hadith narrated by Imam Bukhari and Muslim from Aisyah RA:

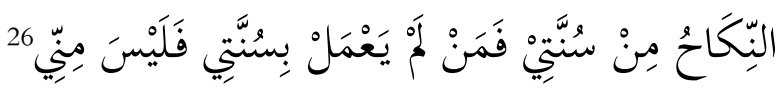

"Marriage is part of my sunnah, whoever does not practice my sunnah, then is not included in my group".

This hadith explains that people who do not want to get married are not included in the group of Muhammad's people. Even though marriage is a sunnah from the teachings of the Prophet Muhammad, it is also necessary for us to weigh the benefits and harms that will apply after marriage.

e. Physical and Mental Readiness is the basic principle of a marriage to take place: Are our children who are going to get married mentally and physically ready, two components that greatly influence the journey of a couple's life after marriage. Because people who get married at a very young age will have an impact on their mental and physical, readiness to face the various waves of a harsh life 27 . If you are mentally prepared to face all obstacles and obstacles, then hastening to marry your child is the right action. Hastening something good is a matter of worship. However, if you are not mentally ready, then postponement of

24 Galuh Nasrullah, et.al," "Konsep Maqashid al-syariah dalam membentuk Hukum Islam (Perspektif al-Syatibi dan Jasser Audah)", Journal Ekonomi Syariah dan Hukum Ekonomi Syariah, Vol. 1, Desember 2015, 66

25 Kisworo, B., \& Hardivizon, H. (2020). Telaah Leksikal, Gramatikal, dan Kontekstual Terhadap Makna Kata Syahida pada QS. al-Baqarah ayat 185. AL QUDS : Jurnal Studi Alquran dan Hadis, 4(1), 163-180. doi:http://dx.doi.org/10.29240/alquds.v4i1.1473

${ }^{26}$ Abu Abdullah Muhammad bin Islamil al-Buk hari, Sahih Al-Bukhari, Kitab alNikah Bab Man Raghiba 'an sunnari Rasulillah, no. Hadis 1919

27 Abu Ishaq Al-Syathibi, al-Muwafaqat fi Ushul al-Syari"ah, (Beirut: Dar alKutub al-Islamiyah, t.t), II, 12 
marriage is the right way. Although marriage is worship, it is not timebound worship in its implementation, but it is necessary to wait for the right time for its implementation ${ }^{28}$.

Here the role of a marriage guardian is very important, where he must determine whether the marriage can be continued or should be postponed until everything is ready. If he deliberately and wants to continue the marriage, while his child is not ready, then he has plunged his children to the brink of destruction. Such things must be avoided, as outlined by the Shari'a that anything that harms must be shunned and avoided. As the word of Allah in Surah al-Baqarah, 2:195:

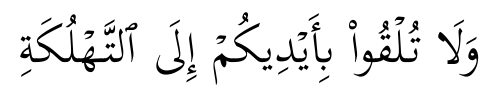

Meaning: and do not throw yourself into destruction.

\section{Conclusion}

Marriage is a worship that draws closer to God, it takes physical and mental readiness to realize it. Marriage is a long journey that will be decorated with many problems and problems. Especially for couples at an early age and especially on the woman's side, who are physically not yet perfect to go through it and mentally are not yet strong enough to endure the problems they are experiencing.

In terms of health, early marriage actors face problems from physical or mental. Physically, a woman who marries too young will face the problem of unprepared female sex organs so that the perpetrators of early marriage will experience a miscarriage, the child will be born with a disability or will die during childbirth, or will die during the first night. As for mentally, perpetrators of early marriage often experience panic in raising children and feel inferior when they meet their peers who are still wearing school uniforms and the economic stability of early marriage partners.

Islamic law requires goodness in all sides of human life, this is all reflected in the maqashid al-Shariah whose main purpose is to maintain

${ }^{28}$ M. Atho Mudzhar, Fatwa-fatwa Majlis Ulama Indonesia : Sebuah studi tentang Pemikiran Hukum Islam di Indonesia 1975-1998, (Jakarta: Indonesia Netherlands Cooeratiion in Islamic Studies, 1993), 87 
five things, if these five cases are maintained, the regularity of human social life will be guaranteed. The five things are guarding the din (religion), guarding the nafs (soul), guarding 'aql (reason), guarding nasl (descendants), and guarding al-mal wa al-irdh (wealth and honor). The marriage that is prescribed by Islam aims to maintain offspring. Although it has a big role in maintaining offspring, attention must be paid to the implementation of marriage, especially for underage couples (early marriage), where Imam Shafi'i allows its implementation on the condition that it will bring benefit to the couple, if the marriage will cause harm then it must be annulled. . The role of the guardian is very large in the process of early marriage, where a guardian can determine the validity of a marriage, if he sees his child's marriage will bring benefits then he should carry it out while if it will cause harm then he must cancel it. That would certainly be closer to goodness.

\section{Bibliography}

Abu Ishaq Al-Syathibi, al-Muwafaqat fi Ushul al-Syari"ah, Beirut: Dar alKutub al-Islamiyah, n.d.

Achrory and Siska Iriani, "Fenomena Pernikahan Dini Dalam Perspektif Islam (Studi Kasus Di Desa Kalikuning)", Jurnal Penelitian Keislaman, 14(2), 2018.

Ahmad Raysuni dan Muhammad Jamal Barut, Ijtihad anatara teks, realitas dan kemaslahatan sosial, Jakarta:Erlangga, 2002.

Amir Syarifudin, Garis-Garis Besar Fiqh, Jakarta: Kencana, 2003.

Andopa, A., Hardivizon, H., \& Yunita, N. (2018). The Meaning of Nafs in the Qur'an Based on Quraish Shihab's Interpretation. AJIS: Academic Journal of Islamic Studies, 3(2), 139-162. doi:http://dx.doi.org/10.29240/ajis.v3i2.578

Asafri Jaya Bakri, Konsep Maqashid al_syari'ah menurut al-syatibi, Jakarta: PT Raja Grafindo, 1996.

Dwi Rifiani, "Pernikahan Dini Dalam Perspektif Hukum Islam", de Jure, Jurnal Syariah dan Hukum, 3(2), 2011, 125-134

Galuh Nasrullah, et.al, "Konsep Maqashid al-syariah dalam membentuk Hukum Islam (Perspektif al-Syatibi dan Jasser Audah)”, Journal 
Ekonomi Syariah dan Hukum Ekonomi Syariah, Vol. 1, Desember 2015.

Habibah Nurul Umah, "Fenomena Pernikahan Dini di Indonesia Perspektif Hukum-Keluarga-Islam", Jurnal Al Wasith: Jurnal Studi Hukum Islam, 5(2), 2020, 107-125Kamarusdiana and Ita Sofia, "Dispensasi Nikah Dalam Perspektif Hukum Islam, Undang-Undang Nomor 1 Tahun 1974 dan Kompilasi Hukum Islam", SALAM; Jurnal Sosial \& Budaya Syar-i, 7(1), 2020, pp.49-64, DOI: 1 10.15408/sjsbs.v7i1.14534

Ibrahim Mustafa, al-Mu'jam al-Wasith, Istanbul: al-Maktabah alIslamiyyah, 1999.

Jaih Mubarak, Metodologi Ijtihad Hukum Islam, Jogjakarta: UII Press, 2002.

Kisworo, B., \& Hardivizon, H. (2020). Telaah Leksikal, Gramatikal, dan Kontekstual Terhadap Makna Kata Syahida pada QS. al-Baqarah ayat 185. AL QUDS : Jurnal Studi Alquran dan Hadis, 4(1), 163-180. doi:http://dx.doi.org/10.29240/alquds.v4i1.1473

Marieyam, "Pelaksanaan Perkawinan Usia Dini Setelah Berlakunya UU RI Nomor 1 Tahun 1974 “ Tesis. ( Semarang: Perpustakaan Universitas Diponegoro Semarang 2017).

Muhammad Said Ramadhan al-Buthy, Dawabit al-maslahah fi al-syariah al-Islamiyyah, Beirut:Dar al-Muttahidah, 1992.

M. Atho Mudzhar, Fatwa-fatwa Majlis Ulama Indonesia : Sebuah studi tentang Pemikiran Hukum Islam di Indonesia 1975-1998, Jakarta: Indonesia Netherlands Cooeratiion in Islamic Studies, 1993.

Suryono, Pernikahan Dini Pada Masyarakat Lebong Utara : Tinjauan Sosiologis dan Normatif, Tesis, IAIN Curup

Yusuf Qaradhawi, Membumikan Syari'at Islam, Keluwesan aturan Illahi untuk Manusai, Bandung: Pustaka Mizan, 2003. 